\title{
Same Mindset, Different Pedagogical Strategies: A Case Study Comparing Chinese and Finnish Teachers
}

\author{
Junfeng Zhang* \\ University of Helsinki \\ Helsinki, Finland \\ Elina Kuusisto \\ Tampere University \\ Tampere, Finland \\ Kirsi Tirri \\ University of Helsinki \\ Helsinki, Finland
}

\begin{abstract}
Given that little is known about the correlations between teachers' mindset and their pedagogical strategies, in this article, we explore Chinese and Finnish teachers' mindsets and their pedagogical strategies from the perspective of praise and adaptive teaching. This study was conducted in two Chinese schools $(\mathrm{N}=50)$ and one Finnish school $(\mathrm{N}=77)$ with instruments of the mindset inventory, praise scale and adaptive learning scale (PALS). The results reveal that Chinese and Finnish teachers' preferences for pedagogical strategies differ even though they hold the same growth mindset, which confirms that teachers do not necessarily utilize growth mindset messages even though they endorse a growth mindset. While Finnish teachers prefer pedagogical methods in accordance with growth mindset pedagogy, Chinese teachers seem to apply mixed strategies reflecting both growth and fixed mindsets. The results imply differences within Finnish and Chinese teacher education regarding the internalization of the principles of growth mindset pedagogy.
\end{abstract}

Keywords: Mindset; pedagogical strategy; praise; adaptive teaching

•Corresponding author: junfeng.zhang@helsinki.fi, zhouxixijay1991@gmail.com 


\section{Introduction}

Mindsets, also known as implicit theories, are beliefs held by individuals about the malleability of basic qualities, such as intelligence (Dweck, 2006). Numerous studies over several decades have shown how mindset is associated with learning performance (Blackwell, Trzesniewski, \& Dweck, 2007; Dweck, Walton, \& Cohen, 2014; Zhang, Kuusisto, \& Tirri, 2019). People with a growth mindset (the incremental theory) acknowledge that individual qualities can be nurtured, and they prefer to undertake challenging tasks and expend effort, often leading to the attainment of higher levels of achievement. By contrast, people with a fixed mindset (the entity theory) are of the opinion that human qualities are immutable, and they are inclined to avoid risks and devalue effort, which usually results in achieving less than their full potential (Dweck, 2017).

Mastery goals (i.e., learning goals) and performance goals have been identified as learning orientations associated with the growth and fixed mindset, respectively (Dweck, 2000). Individuals with mastery goals are oriented toward developing new skills and competencies, whereas those with performance goals tend to demonstrate their skills and avoid any indications of incompetence. In the seminal work by Dweck and Leggett (1988), a research-based model was developed to specify how individuals' implicit theories orient them toward particular goals. More specifically, an incremental theorist is apt to pursue mastery goals and adopt mastery-oriented behavioural patterns (e.g., seeking challenges), whereas an entity theorist values performance goals and helpless behavioural patterns (e.g., avoiding risks). That adaptive and maladaptive patterns can be predicted by underlying psychological processes has been verified by several empirical studies. For example, when testing a mediational model, Blackwell et al. (2007) found that American adolescents who were taught about the incremental theory later endorsed mastery goals. Moreover, consistent with such results from Western societies, the Chinese university students with an incremental view of intelligence are believed to be more likely to set mastery goals, increase their knowledge and satisfy their curiosities (Chen \& Wong, 2015).

Equally noteworthy, however, is the fact that empirical studies have challenged Dweck's theory, especially regarding the link between individuals' mindsets and their behaviours. For instance, Leondari and Gialamas (2002) observed that "incremental beliefs were not related to academic achievement" (p. 287) among Greek elementary and lower-secondary school students, which corresponds to a similar conclusion for the American undergraduates made by Robins and Pals (2002). Moreover, a further study among the French students failed to find a correlation between mindset and participants' goal orientation and cognitive engagement in learning (Dupeyrat \& Mariné, 2005). A possible explanation for such contrary results might be that, rather than affecting achievement directly, mindset operates through mediators, such as students' goal orientation (Zhang, Kuusisto, \& Tirri, 2017), teachers' mastery vs. performance-oriented instructional practices (Park, Tsukyama, Gunderson, Levine, \& Beilock, 2016) or teachers' mindset-related messages, such as process-focused or person-focused praising (e.g., Schmidt, Shumow, \& Kackar-Cam, 2015).

Research results on the relationship between teachers' mindsets and their teaching practices also appear to vary. On one hand, teachers' pedagogical 
practices seem to reflect their implicit theories. For example, the endorsement of incremental theories is demonstrated in teachers' process-focused pedagogical thinking as well as in their classroom interaction (Rissanen, Kuusisto, Hanhimäki, \& Tirri, 2018; Rissanen, Kuusisto, Tuominen, \& Tirri, 2019). Further, growthmindset teachers engender supportive autonomy in their interactions with students (Leroy, Bressoux, Sarrazin, \& Trouilloud, 2007).

Conversely, teachers with entity theories are likely to adopt performance-oriented (Park et al., 2016) and unproductive (Rattan, Good, \& Dweck, 2012) pedagogical practices. They view themselves as less responsible for students' academic performance (Patterson, Kravchenko, Chen-Bouck, \& Kelley, 2016; Rissanen et al., 2018). On the other hand, regardless of their personal implicit beliefs, highly educated teachers seem able to provide consistent support for their students' learning processes, mastery orientation, and process-focused thinking, which have been identified as core features of growth mindset pedagogy (Rissanen et al., 2019). Rissanen, Kuusisto, Tuominen and Tirri (2019) also identified one critical aspect of such growth mindset pedagogy, for instance, a highly educated teacher in the investigation failed to teach academically talented students how to cope with setbacks and tackle learning challenges. Schmidt, Shumow and KackarCam (2015) observed that even though teachers seem to hold a growth mindset, they do not necessarily utilise growth mindset messages in their teaching practice.

Based on Schmidt et al.'s study (2015) students of teachers who implement the principles of growth mindset pedagogy are more likely to enjoy long-lasting benefits from the mindset intervention, such as beliefs about the malleability of intelligence, mastery-oriented learning goals and better academic achievement. This positive effect on academic grades has been verified by an online growth mindset intervention among lower-achieving students in secondary education (Yeager et al., 2019). These results correspond to Rattan, Good and Dweck's (2012) earlier finding that teachers' performance-oriented pedagogy (comfort feedback) lowers both students' motivation and expectations for their academic performance.

The majority of previous mindset studies have investigated students' perspectives, while research on teachers has remained relatively scarce (e.g., Zhang et al., 2017). Moreover, studies on teachers have mainly surveyed the connection between mindset and a single pedagogical strategy, such as praising style (Jonsson \& Beach, 2012). However, to the authors' knowledge, little is known about the correlation between teachers' mindsets and other pedagogical behaviours, such as goal orientation. Thus, the implications of teachers' mindsets for their pedagogical practices, especially from the perspective of both praise and goal orientation, have remained understudied. Consequently, the present study investigates and compares Chinese and Finnish teachers' mindsets and pedagogical preferences by answering the following research questions:

1) What kinds of mindsets about learning do Chinese and Finnish teachers hold?

2) What kinds of pedagogical strategies do Chinese and Finnish teachers prefer

- from the perspective of goal orientation?

- from the perspective of praise? 
3) How do Chinese and Finnish teachers' mindsets relate to their pedagogical strategies?

\section{Research context: Teacher education in China and Finland}

\subsection{China}

As indicated in Table 1, although the teaching profession can be traced back to Confucian times, the formal establishment of teacher education in China is considered to have begun by the 1900s (Guo, 2005; Li, 2012, 2013) with the first teaching training school, Nanyang Gongxue, in 1897, and to have developed especially after the establishment of the People's Republic of China in 1949 (Wen, 1989). To improve the social position of teachers, the first national Teachers' Day was celebrated in 1985, and the Law of Teachers was formulated in 1993 to guarantee teachers' legal rights. In 2010, the "Outline of China's National Plan for Medium and Long-term Education Reform and Development 2010-2020" was issued as China's first major educational initiative of the 21st century.

Today, the main institutions to offer teacher education in China are specialized universities and colleges and, increasingly, comprehensive universities with separate educational study programmes (State Council of People's Republic of China, 2010; Li, 2012). In China, all teachers in compulsory basic education are subject teachers who instruct in one specific subject; thus, their studies consist of their respective subjects and educational science, including teaching practice. Student teachers are usually selected based on the National College Entrance Examination. Generally, elementary teachers are required to hold an associate degree (3 years) (State Council of People's Republic of China, 2010), while a Bachelor's degree (4 years) is essential for secondary teachers ( $\mathrm{Li}, 2012)$. Moreover, for some secondary school teachers in economically developed regions, graduate studies (2-3 years) are mandatory (Ministry of Education, 2002; Li, 2012).

As for the current aim of Chinese teacher education, quality improvement is considered the core task of education reform and development, and moral behaviour has been identified as the foremost factor when employing and evaluating teachers (State Council of People's Republic of China, 2010). In China, all prospective teachers must hold a teaching qualification, which is obtained after passing the teacher qualification test, comprised of a written examination, lecturebased structured and language assessment for Mandarin Chinese (Ministry of Education, 2013). Further, since 2015, in-service teachers' teaching qualification certificates have been evaluated every fifth year for moral behaviour, annual performance and teacher training (Ministry of Education, 2013). In addition, the Chinese government offers financial and administrative support to guarantee the living standard of the teaching community, such as improving teachers' living and working conditions, guaranteeing the teachers a minimum salary that's no less than the average salary of the country's civil servants and introducing medical and retirement insurance schemes (State Council of People's Republic of China, 2010). More importantly, free education with a living allowance has been introduced for student teachers at key Chinese national universities specializing in teacher training. 


\subsection{Finland}

Finnish teacher education originated from the establishment of the first professorial chair at the University of Helsinki in 1852 and the founding of the first teacher-training seminar in 1863. The formulation of the Teacher Education Act in 1971 resulted in the reassignment of class teacher education to universities in 1974 and the requirement of a Master's degree for both elementary and secondary school teachers (Kansanen, 2003).

Teacher education in Finland is provided in eight Finnish comprehensive universities (Niemi \& Jakku-Sihvonen, 2011). Teacher education for elementary and secondary school teachers involves a two-tier degree system comprising a three-year bachelor's degree and a two-year Master's degree (Bachelor $180+$ Master $120=300$ Credits). In basic education, teachers are divided into class teachers (teaching all subjects in elementary schools) and subject teachers (teaching at least one subject in lower secondary schools). Class teachers major in educational science, in which they study multidisciplinary subjects and crosscurricular themes and complete teachers' pedagogical studies $(60$ credits, including approximately 20 credits of guided teaching practice). By contrast, subject teachers begin by studying their respective subjects, then, usually after two years, they apply for teachers' pedagogical studies.

Teacher education has traditionally been one of the most sought-after study programmes in Finland, with only 10-15 percent of applicants successfully acquiring a place (Niemi \& Jakku-Sihvonen, 2011). The selection procedure consists of an academic examination and interviews to assess the applicants' motivation for entering the teaching profession and their social and communicational skills (Kansanen, 2003; Niemi \& Jakku-Sihvonen, 2011).

Finnish teacher education aims at enabling teachers to make educational decisions based on rational argumentation in addition to everyday or intuitional argumentation (Kansanen, 2003). In addition, Finnish teacher education is research-based, aiming to educate teachers who are able to think pedagogically and combine academic research with practical teaching (Tirri, 2014). Then, pedagogical thinking, especially regarding equality and autonomy, is seen as essential for producing overall high-quality education, as the central objective of Finnish education has been to provide all citizens with equal opportunities (Finnish National Agency for Education, 2016). In order to highlight the moral aspect of the teaching profession, ethical codes for teachers were published in 1998. Moreover, teachers' pedagogical autonomy has been embedded into each administrative level of the Finnish educational system. For instance, municipal authorities and local schools have been granted the right to manage funding allocation and personnel recruitment, and teachers enjoy autonomy in choosing teaching methods and materials (Zhang et al., 2019). Thirdly, the Finnish educational system highlights the individualistic and holistic development of students in addition to their academic achievement (Kuusisto, Laine, \& Tirri, 2017). Thus, teachers are expected to create an integrative, innovative, and inclusive learning environment. Additionally, teachers require high-level ethical and pedagogical skills to cope with the challenges created by the growing number of immigrant students (Tirri, 2014). 
Table 1. Teacher education in China and Finland for basic education

\begin{tabular}{|c|c|c|c|}
\hline \multirow{3}{*}{ History } & & China & Finland \\
\hline & Beginning & $1900 \mathrm{~s}$ & $1860 \mathrm{~s}$ \\
\hline & $\begin{array}{l}\text { Major } \\
\text { events }\end{array}$ & $\begin{array}{l}\text {-1st teacher training school (1897) } \\
\text {-1st Teachers' Day (1985) } \\
\text {-Law of Teachers (1993) } \\
\text {-Outline of China's National Plan } \\
\text { for Medium and Long-term } \\
\text { Education Reform and } \\
\text { Development 2010-2020 (2010) }\end{array}$ & $\begin{array}{l}\text {-1st professorship in education (1852) } \\
\text {-1st teacher training college (1863) } \\
\text {-Teacher Education Act (1971) } \\
\text {-Ethical code for teachers (1998) }\end{array}$ \\
\hline $\begin{array}{l}\text { Teacher } \\
\text { classification }\end{array}$ & & Subject teachers & $\begin{array}{l}\text { Elementary: Class teachers } \\
\text { Lower secondary: Subject teachers }\end{array}$ \\
\hline \multirow{3}{*}{$\begin{array}{l}\text { Learning } \\
\text { programs }\end{array}$} & Institute & Universities and colleges & Universities \\
\hline & Enrolment & National academic examination & Academic examination + Interview \\
\hline & Curriculum & $\begin{array}{l}\text {-Respective subject } \\
\text {-Educational science }\end{array}$ & $\begin{array}{l}\text { Class teachers: Educational science + } \\
\text { pedagogical studies } \\
\text { Subject teachers: Respective subject + } \\
\text { pedagogical studies }\end{array}$ \\
\hline \multirow[t]{2}{*}{ Qualification } & Degree & $\begin{array}{l}\text { Elementary: Associate degree } \\
\text { Lower secondary: Bachelor }\end{array}$ & Master \\
\hline & Certificate & Teacher qualification certificate & $\begin{array}{l}\text { Teacher's pedagogical studies } \\
\text { (60 credits) }\end{array}$ \\
\hline Current aims & & $\begin{array}{l}\text {-Teaching quality improvement } \\
\text {-Moral behaviour of teachers } \\
\text { - Guarantee of living standard }\end{array}$ & $\begin{array}{l}\text {-Research-based teacher education } \\
\text {-Pedagogical thinking } \\
\text {-Inclusive learning environment }\end{array}$ \\
\hline
\end{tabular}

\section{Data and Methods}

\subsection{Participants and procedure}

As shown in Table 2, teachers from two Chinese schools $(N=50)$ and one Finnish school $(\mathrm{N}=77)$ participated in the survey from 2017 to 2018. Among them, 24 teachers worked at the elementary level and 26 at the lower-secondary level in the Chinese sample, while 40 teachers worked at the elementary level and 37 at the lower-secondary level in Finland. The Chinese school was located in the southwestern rural region of Sichuan province, which represents a relatively low socioeconomic area, while the Finnish school was situated in a less-affluent suburb of the Helsinki metropolitan area.

As can be seen in Table 2, up to $97.4 \%$ of the Finnish teachers held a Master's degree, while $54.0 \%$ of the Chinese teachers held a bachelor's degree and the remaining $46.0 \%$ an associate's degree. The majority $(81.8 \%)$ of the Finnish teachers were female compared to under half $(44.0 \%)$ of their Chinese peers. Moreover, the average age of the Finnish teachers $(M=41.80, S D=11.128)$ was 10 years higher than the Chinese teachers $(M=32.80, S D=9.602)$, and the Finnish educators had much more teaching experience $\left(M_{\mathrm{Fin}}=12.34, S D=9.851 ; M_{\mathrm{Ch}}=\right.$ $9.98, S D=10.467)$. All the Chinese teachers spoke Mandarin Chinese as their first language, whereas $96.1 \%$ of the Finnish teachers considered Finnish their first language.

The principals of the Chinese schools provided meeting rooms in which the teachers could participate in the study, where the first author was present to 
introduce the details and distribute the printed versions of the questionnaires. Some teachers completed the questionnaires at that point, while others later returned the survey to the principal's office. The Finnish data were collected with an online questionnaire utilizing Qualtrics software. The average completion time was around 20 minutes. In both countries, consent for the teachers' participation was obtained from the schools' administration and the teachers themselves.

Table 2. Participant demographics

\begin{tabular}{l|lll}
\hline & China & Finland & In total \\
& $\mathrm{N}=50(26.3 \%)$ & $\mathrm{N}=77(73.7 \%)$ & $\mathrm{N}=127$ \\
\hline Gender & & & \\
Female & $22(44.0 \%)$ & $63(81.8 \%)$ & $85(66.9 \%)$ \\
Male & $28(56.0 \%)$ & $14(18.2 \%)$ & $42(33.1 \%)$ \\
\hline Age & $32.80(9.602)$ & $41.80(11.128)$ & $38.27(11.406)$ \\
\hline $\begin{array}{l}\text { First language } \\
\text { Finnish }\end{array}$ & & & \\
Chinese & $50(100.0 \%)$ & & $74(96.1 \%)$ \\
Other & & $3(3.9 \%)$ & $50(39.4 \%)$ \\
\hline Teaching experience (year) & $9.98(10.467)$ & $12.34(9.851)$ & $3(2.3 \%)$ \\
\hline Education degree & & & $11.41(10.121)$ \\
Associate degree & $23(46.0 \%)$ & & $23(18.3 \%)$ \\
Bachelor & $27(54.0 \%)$ & $2(2.6 \%)$ & $29(23.0 \%)$ \\
Master & & $74(97.4 \%)$ & $74(58.7 \%)$ \\
\hline $\begin{array}{l}\text { School } \\
\text { Primary School }\end{array}$ & $24(48.0 \%)$ & $40(52.6 \%)$ & $64(50.8 \%)$ \\
Secondary School & $26(52.0 \%)$ & $36(47.4 \%)$ & $62(49.2 \%)$ \\
\hline
\end{tabular}

$\mathrm{Ch}=$ China, Fin $=$ Finland

\subsection{Measurement instruments}

This study measured teachers' perceptions of mindset and the pedagogical strategies they preferred to adopt. The self-evaluated survey consisted of the following instruments: the Implicit Theory of Intelligence (ITI, Dweck, 2000), the Implicit Theory of Giftedness (ITG, Dweck, 2000; Kuusisto et al., 2017), the Patterns of Adaptive Learning Scale (PALS, Midgley et al., 2000), and Praise (created based on Gunderson et al., 2013).

Both the ITI and ITG instruments utilized a 6-point Likert scale (1 = strongly agree, $6=$ strongly disagree) to record participants' attitudes to the nature of intelligence and giftedness respectively, among which values above 3.5 indicated a growth mindset and values below 3.5 a fixed mindset. The items of the ITI and ITG are presented in Table 3.

By contrast, the PALS (items shown in Table 4) utilized a 5-point Likert scale ( $1=$ strongly disagree, 5 = strongly agree). Nine original items were modified to measure the extent to which teachers would like to adopt the given pedagogical strategies to support their students' performance goal orientation (PGO) and mastery goal orientation (MGO).

In turn, a total of 16 praise statements reflected the oral praise that teachers preferred to offer when their students achieved exceptional academic grades, as indicated in Table 5. The instrument was developed based on Gunderson et al.'s 
(2013) study on process, person and neutral praising styles. In addition, items indicating luck were also included. The items were scored on a 5-point Likert scale ( $1=$ strongly disagree, $5=$ strongly agree).

\subsection{Statistical analysis}

Chinese and Finnish samples were analyzed with similar methods. First, the IBM Statistical Package for Social Sciences (SPSS) version 25 was used to estimate missing values: there were none $(0.0 \%)$ in the Chinese sample and very few $(0.5 \%)$ in the Finnish sample. According to Little's MCAR test, the data were missing completely at random (China: no EM estimated statistics given that there were no missing values; Finland: $\left.\chi^{2}(53)=68.365, p=.076\right)$.

Second, combining previous theoretical underpinnings about the given four instruments (ITI, ITG, PALS, Praise), exploratory factor analysis approach (EFA) with the principal component extraction and direct oblimin rotation in SPSS 25 was performed to identify the latent factors. The Cronbach's alpha value was calculated to test the internal reliability.

Third, given the fact of ordinal variables, small sample size and non-normality of data distribution in the present study, correlation analyses were performed with non-parametric methods, using Spearman's Rho, to identify the correlations between mindset and pedagogical strategies (Hauke \& Kossowski, 2011).

\section{Results}

\subsection{Teachers' mindsets about learning}

To answer the question of what mindsets about learning that Chinese and Finnish teachers hold, we began the analysis by calculating the Cronbach's alpha values of the ITI and ITG for the Chinese and Finnish teachers separately. The internal reliability for the ITI $\left(\alpha_{\mathrm{Ch}}=.725, \alpha_{\mathrm{Fin}}=.900\right)$ and ITG $\left(\mathrm{a}_{\mathrm{Ch}}=.820, \mathrm{a}_{\mathrm{Fin}}=.953\right)$ indicated acceptable, good and excellent consistencies (Chen, 2014). Among the Chinese teachers, the mean scores for intelligence $(M=4.34, S D=.913)$ and giftedness $(M=4.02, S D=1.076)$ were above 3.5 , demonstrating the Chinese teachers' growth mindset. One sample t-test revealed that the difference between the two mean scores was statistically significant $\left(t_{\text {ТтІ }}(49)=6.506, p<.001, d=.92\right.$; $\left.t_{\text {ITG }}(49)=3.417, p<.01, d=.48\right)$. Meanwhile, a paired sample t-test proved that the Chinese teachers identified intelligence as more malleable than giftedness $(t(49)=$ $2.721, p<.01, d=.38$ ). Among the Finnish teachers, there appeared to be the same growth mindset tendency $\left(M_{\mathrm{ITI}}=4.54, S D=.886 ; t_{\mathrm{TTI}}(76)=10.253, p<.001, d=1.17\right.$; $\left.M_{\mathrm{ITG}}=4.16, S D=1.12 ; t_{\mathrm{ITG}}(76)=5.192, p<.001, d=.59\right)$, and the Finnish teachers also considered intelligence to be more changeable $(t(76)=2.801, p<.01, d=.32)$ than giftedness. An independent-samples t-test found no significant differences between the Chinese and Finnish teachers regarding the nature of intelligence $(t(125)=1.201, p=.232, d=.21)$ or giftedness $(t(125)=.711, p=.479, d=.13)$. 
Table 3. Items, means and standard deviations of Implicit Theories of Intelligence (ITI) and Giftedness (ITG)

\begin{tabular}{|c|c|c|}
\hline \multirow[b]{2}{*}{ Item } & \multicolumn{2}{|c|}{ M (SD) } \\
\hline & $\begin{array}{l}\text { China } \\
(\mathrm{N}=50)\end{array}$ & $\begin{array}{l}\text { Finland } \\
(\mathrm{N}=77)\end{array}$ \\
\hline Mindset about Intelligence (ITI) & $\begin{array}{c}4.34(.913) \\
a=.725\end{array}$ & $\begin{array}{c}4.54(.886) \\
a=.900\end{array}$ \\
\hline $\begin{array}{l}\text { (1) You have a certain amount of intelligence, and you really can't } \\
\text { do much to change it. }\end{array}$ & $4.76(1.021)$ & $4.68(1.044)$ \\
\hline (2) Your intelligence is something that you can't change very much. & $4.04(1.245)$ & $4.51(1.021)$ \\
\hline (3) To be honest, you can't really change how intelligent you are. & $4.46(1.216)$ & $4.68(.924)$ \\
\hline $\begin{array}{l}\text { (4) You can learn new things, but you can't really change your basic } \\
\text { intelligence. }\end{array}$ & $4.10(1.418)$ & $4.29(1.050)$ \\
\hline Mindset about Giftedness (ITG) & $\begin{array}{c}4.02(1.076) \\
a=.820\end{array}$ & $\begin{array}{l}4.16(1.120) \\
a=.953\end{array}$ \\
\hline $\begin{array}{l}\text { (1) You have a certain amount of giftedness, and you really can't do } \\
\text { much to change it. }\end{array}$ & $4.10(1.216)$ & $4.30(1.171)$ \\
\hline (2) Your giftedness is something that you can't change very much. & $3.94(1.331)$ & $4.14(1.155)$ \\
\hline (3) To be honest, you can't really change how gifted you are. & $4.06(1.376)$ & $4.19(1.203)$ \\
\hline $\begin{array}{l}\text { (4) You can learn new things, but you can't really change your basic } \\
\text { giftedness. }\end{array}$ & $3.98(1.407)$ & $4.01(1.251)$ \\
\hline
\end{tabular}

\subsection{Teachers' preferred pedagogical strategies in supporting students' goal orientation}

To answer the question of what pedagogical strategies Chinese and Finnish teachers prefer from the perspective of goal orientation, Cronbach's alpha values for PGO and MGO were calculated among the Chinese and Finnish teachers separately. For the Chinese teachers, this yielded a poor level of reliability regarding PGO $(\alpha=.551)$ and MGO $(\alpha=.541)$, which needed to be considered when interpreting the results (Chen, 2014). By contrast, the results illustrated an acceptable and good level of reliability for the Finnish teachers' PGO $(\alpha=.725)$ and MGO $(\alpha=.820)$.

Among the Chinese teachers, the mean scores for PGO $(M=4.08, S D=.496)$ and MGO $(M=4.11, S D=.498)$ were above 3.0, indicating they were prone to adopt teaching strategies relating to both performance and mastery goal orientation.

This was also verified by one sample t-test $\left(t_{\mathrm{PGO}}(49)=12.656, p<.001, d=1.79\right.$; $\left.t_{\mathrm{MGO}}(49)=19.483, p<.001, d=2.76\right)$. In turn, the Finnish teachers appeared to have adopted mastery goal orientation $(M=3.85, S D=.821 ; t(75)=-5.871, p<.001, d=$ $.67)$ but not performance goal orientation $(M=2.49, S D=.762$; $t(75)=8.982, p<$ $.001, d=1.02)$. This was confirmed by a paired sample t-test: Finnish teachers utilized MGO more than PGO $(t(75)=-8.491, p<.001, d=.97)$. Furthermore, independent-samples t-test revealed that the usage of both PGO and MGO among Chinese teachers was more frequent than it was among their Finnish peers $\left(t_{\mathrm{PGO}}(123.408)=-12.299, p<.001, d=2.21 ; t_{\mathrm{MGO}}(117.062)=-2.573, p<.05, d=.48\right)$. 
Table 4. Items, means and standard deviations of Patterns of the Adaptive Learning Scale (PALS)

\begin{tabular}{lcc}
\hline & \multicolumn{2}{c}{ M(SD) } \\
\hline Item & $\begin{array}{c}\text { China } \\
(\mathrm{N}=50)\end{array}$ & $\begin{array}{c}\text { Finland } \\
(\mathrm{N}=76)\end{array}$ \\
\hline Performance Goal Orientation (PGO) & $\mathbf{4 . 0 8 ( . 4 9 6 )}$ & $\mathbf{2 . 4 9 ( . 7 6 2 )}$ \\
& $\boldsymbol{a}=.551$ & $\boldsymbol{a}=.761$ \\
\hline (1) I give special privileges to students who do the best work. & $2.86(1.107)$ & $2.62(1.107)$ \\
(3) I display the work of the highest achieving students as an example. & $3.82(.774)$ & $2.87(1.147)$ \\
(6) I help students understand how their performance compares to others. & $4.18(.691)$ & $2.34(.974)$ \\
(7) I encourage students to compete with each other. & $4.08(.804)$ & $2.08(1.080)$ \\
(8) I point out those students who do well as a model for the other students. & $4.22(.764)$ & $2.53(1.013)$ \\
\hline Mastery Goal Orientation (MGO) & $\mathbf{4 . 1 1 ( . 4 9 8 )}$ & $\mathbf{3 . 8 5}(.821)$ \\
& $\boldsymbol{a}=.541$ & $\boldsymbol{a}=.874$ \\
\hline (2) In particular, I will pay attention to the pupil's individual development. & $4.18(.482)$ & $3.79(1.087)$ \\
(4) During class, I often provide several different activities so that students & $4.00(.535)$ & $3.72(.858)$ \\
can choose among them. & $4.32(.713)$ & $4.00(.938)$ \\
(5) I consider how much students could improve when I give their report & & \\
card grades. & $4.02(.795)$ & $3.87(.957)$ \\
(9) I give a wide range of assignments, matched to students' needs and skill & & \\
levels. & & \\
\hline
\end{tabular}

The items in italics were not included in the Chinese mean variables, since they lowered the alpha values.

4.3 Teachers' preferred pedagogical strategies in praising students' academic achievements

To answer the question of how Chinese and Finnish teachers' mindsets relate to their pedagogical strategies from the perspective of praise, similar analyses were utilized as above. The Cronbach's alpha values for the Chinese data showed internal consistency to be at an acceptable level (Chen, 2014): process praise ( $\alpha=$ $.720)$, person $(\alpha=.744)$, neutral $(\alpha=.776)$ and luck $(\alpha=.713)$. In turn, among Finnish teachers, reliability was good for process praise $(\alpha=.860)$, acceptable for person praise $(\alpha=.726)$, and questionable for neutral $(\alpha=.639)$ and luck $(\alpha=.692)$.

The Chinese teachers were more likely to adopt process $(M=4.13, S D=.704 ; t(49)$ $=11.351, p<.001, d=1.61)$, neutral $(M=3.73, S D=.961 ; t(49)=5.373, p<.001, d=$ $.76)$ and person $(M=3.52, S D=.899 ; t(49)=4.090, p<.001, d=.58)$ praise, with average scores above 3 for each item' (excluding luck praise), which was also verified by a one sample t-test. By comparison, the Finnish teachers were more likely to adopt process $(M=3.65, S D=.894 ; t(76)=6.385, p<.001, d=.73)$ and neutral $(M=3.65, S D=.706 ; t(76)=8.027, p<.001, d=.91)$ praise. However, they were unlikely to praise students' person $(\mathrm{M}=1.94, \mathrm{SD}=.675 ; t(76)=-13.737, p<$ $.001, d=1.57)$ or luck $(M=1.47, S D=.567 ; t(76)=-23.724, p<.001, d=2.70)$. Moreover, a paired sample t-test demonstrated that both Chinese and Finnish teachers utilized process praise more than person praise $\left(t_{\mathrm{Ch}}(49)=6.923, p<.001\right.$, $\left.d=.98 ; t_{\text {Fin }}(76)=15.568, p<.001, d=1.77\right)$. Interestingly, an independent-samples $\mathrm{t}$-test showed that Chinese teachers felt they were more likely to utilize process $(t(125)=-3.202, p<.01, d=.57)$, person $(t(84.206)=-10.613, p<.001, d=1.90)$ and luck $(t(72.256)=-8.877, p<.001, d=2.09)$ praise than were their Finnish peers. 
Table 5. Items, means and standard deviations of Praise scale

\begin{tabular}{lcc}
\hline & \multicolumn{2}{c}{ M (SD) } \\
\hline Item & $\begin{array}{c}\text { China } \\
(\mathrm{N}=50)\end{array}$ & $\begin{array}{c}\text { Finland } \\
(\mathrm{N}=77)\end{array}$ \\
\hline Process & $\mathbf{4 . 1 3}(.704)$ & $\mathbf{3 . 6 5}(.894)$ \\
& $\boldsymbol{a}=.720$ & $\boldsymbol{a}=.860$ \\
\hline (3) You practised a lot and it can be seen in this result! & $4.52(.735)$ & $3.23(1.213)$ \\
(7) I can see that you have put a lot of effort into learning new issues. & $4.44(.837)$ & $4.01(.980)$ \\
(11) It was worthwhile to read for the exam! & $3.34(1.303)$ & $3.53(1.137)$ \\
(15) You must have worked hard for this score! & $4.22(.840)$ & $3.83(.951)$ \\
\hline Neutral & $\mathbf{3 . 7 3 ( . 9 6 1 )}$ & $\mathbf{3 . 6 5}(.706)$ \\
& $\boldsymbol{a}=.776$ & $\boldsymbol{a}=.639$ \\
\hline (1) Wow! That's a really good score! & $3.44(1.402)$ & $2.56(1.175)$ \\
(5) Great! & $4.28(1.089)$ & $4.35(.839)$ \\
(9) Fine result! & $3.46(1.265)$ & $3.94(1.017)$ \\
(13) It went well. & $3.74(1.192)$ & $3.74(1.018)$ \\
\hline Person & $\mathbf{3 . 5 2}(.899)$ & $\mathbf{1 . 9 4}(.675)$ \\
& $\boldsymbol{a}=.744$ & $\boldsymbol{a}=.726$ \\
\hline (2) You are so smart on this subject! & $3.84(1.076)$ & $2.25(1.053)$ \\
(6) You are so gifted! & $4.04(1.195)$ & $2.35(1.061)$ \\
(10) You always do well! & $3.66(1.189)$ & $1.93(.929)$ \\
(14) You were born to be successful! & $2.54(1.313)$ & $1.23(.510)$ \\
\hline Luck & $\mathbf{2 . 7 8 ( . 9 4 0 )}$ & $\mathbf{1 . 4 7}(.567)$ \\
& $\boldsymbol{a}=.713$ & $\boldsymbol{a}=.692$ \\
\hline (4) Here you see, sometimes things just go well! & $3.80(1.107)$ & $1.90(1.083)$ \\
(8) The exam questions seemed to be suitable for you! & $3.02(1.392)$ & $1.53(.836)$ \\
(12) Well done. I guess you guessed that these questions would be asked. & $2.42(1.372)$ & $1.29(.629)$ \\
(16) You were really lucky! & $1.88(1.239)$ & $1.12(.364)$ \\
\hline
\end{tabular}

\subsection{Correlation between mindsets and preferred pedagogical strategies}

To investigate the final question of how Chinese and Finnish teachers' mindsets relate to their pedagogical strategies, correlation analyses were conducted. The results presented in Table 6 show no correlation between Chinese teachers' mindset about learning and their perceptions of their pedagogical practices. By contrast, in Finland, the more teachers held a growth mindset about intelligence, the less they preferred to utilize teaching strategies related to performance goal orientation.

Table 6. Spearman correlations between mindset and pedagogical strategies

\begin{tabular}{lllllllll}
\hline & ITI & ITG & PGO & MGO & Neutral & Person & Process & Luck \\
\hline ITI & & $.342^{* *}$ & $-.334^{* *}$ & .181 & -.022 & -.115 & .171 & -.126 \\
ITG & $.623^{* *}$ & & -.221 & .073 & -.006 & -.058 & .206 & -.073 \\
PGO & .069 & -.034 & & $-.405^{* *}$ & -.066 & $.294^{* *}$ & -.096 & .196 \\
MGO & .148 & .108 & $.288^{*}$ & & .063 & .034 & .108 & -.119 \\
Neutral & .034 & -.009 & $.463^{* *}$ & .170 & & $.282^{*}$ & $.298^{* *}$ & .217 \\
Person & -.014 & -.124 & $.430^{* *}$ & .186 & $.804^{* *}$ & & .190 & $.582^{* *}$ \\
Process & -.051 & -.128 & $.447^{* *}$ & .148 & $.653^{* *}$ & $.774^{* *}$ & & .083 \\
Luck & .053 & -.190 & .214 & .095 & $.556^{* *}$ & $.752^{* *}$ & $.606^{* *}$ & \\
\hline
\end{tabular}

Chinese data are given below the hypotenuse; Finnish data above in italics ${ }^{*} \mathrm{p}<.05,{ }^{* *} \mathrm{p}<.01,{ }^{* * *} \mathrm{p}<.001$ 


\section{Discussion}

Despite the abundant research conducted on students' motivational framework, little is known about teachers' mindset and pedagogical practices. The current study investigated Chinese and Finnish teachers' mindsets and preferred pedagogical strategies from the perspective of goal orientation and praise. The participants were elementary and lower-secondary teachers from two Chinese (N =55) schools and one Finnish $(\mathrm{N}=77)$ school.

The results illustrated that the Chinese and Finnish teachers identified both intelligence and giftedness as malleable; in other words, they demonstrated a growth mindset. Further, the teachers in both samples evaluated intelligence as more changeable than giftedness, a view which has also been identified among the American (Makel et al., 2015), Finnish and Chinese students (Zhang et al., 2017; Zhang et al., 2019).

In turn, the Chinese teachers appeared to prefer mixed pedagogical strategies. The Chinese teachers favoured the adoption of strategies that supported both performance and mastery goal orientation, and they utilized diverse and even contradictory feedback strategies, including process-focused, person-focused and neutral messages. Instead, the Finnish teachers' pedagogical strategies seemed to conform more to Dweck's theory and growth mindset pedagogy, since these teachers were more likely to opt for strategies supporting students' mastery goal orientation than performance goal orientation, and they were also more apt to emphasise process and neutral messages than the student's person or luck when giving praise.

Accordingly, the teachers in China and Finland seemed to adopt different, even opposite, pedagogical strategies despite supporting the same growth mindset. However, among the Chinese teachers no statistically significant correlation was found between mindset and pedagogical strategies, and only one statistically significant correlation was identified among the Finnish teachers: the teachers' mindset about intelligence correlated negatively with a preference for performance goal orientation, indicating that a fixed mindset is associated with supporting students' performance goal orientation.

The Finnish teachers' pedagogical behaviour seemed to align well with previous findings suggesting that teachers who endorse a fixed mindset are more likely to adopt performance-oriented strategies (Park et al., 2016; Rissanen et al., 2018, 2019). The results of the present study indicate that teachers in Finland have been educated on the importance of process feedback and support for mastery orientation, topics that are also emphasised in Finnish National Core Curriculum (Finnish National Agency for Education, 2016). By contrast, Chinese teachers' pedagogical strategies seem to be more mixed and less coherent, implying that Chinese teacher education has yet to adopt the core principles of growth mindset pedagogy in teaching practice. Further, the pedagogical strategies of the Chinese teachers in the current study confirmed earlier research illustrating that teachers do not necessarily utilize growth mindset messages even though they endorse a growth mindset (Schmidt et al., 2015).

In line with previous studies critiquing Dweck' theory, especially the nonsignificant correlation between individuals' mindsets and their behaviours (e.g., 
Dupeyrat \& Mariné, 2005; Leondari \& Gialamas, 2002; Robins \& Pals, 2002), the current study also found relatively weak associations between mindsets and pedagogical strategies. Nevertheless, it seems that high quality, research-based teacher education, such as that provided in Finland (Tirri, 2014), guides teachers to use strategies that are in line with the growth mindset theory (Rissanen et al., 2019). By contrast, the Chinese teachers in the present study adopted more mixed teaching strategies, including multiple and even contradictory strategies.

The present research has implications for both theory and practice. In terms of theory, it enriches the literature on teachers' mindsets and instructional practices with regards to students, since mindset, praise and adaptive teaching among teachers were investigated in a cross-national setting with different cultural and educational features. In terms of practice, since the results confirm that teachers with the same growth mindset might adopt different pedagogical strategies, it provides evidence of the necessity of educating pre-service and in-service teachers on selecting the appropriate strategy.

With its relatively small sample size, the present study was, however, unable to test the possible effect of background variables, such as teachers' educational degree and length of teaching experience, on their pedagogical strategies. The different cultural backgrounds might cause aggregation bias or heterogeneity. Finally, given that this research is just a case study, the implication might be conservative. Thus, big samples and in-depth analysis of the direct or indirect impact of teachers' background variables are required in future research.

\section{References}

Blackwell, L. S., Trzesniewski, K. H., \& Dweck, C. S. (2007). Implicit theories of intelligence predict achievement across an adolescent transition: A longitudinal study and an intervention. Child Development, 78(1), 246-263. doi:10.1111/j.14678624.2007.00995.x

Chen, W. W., \& Wong, Y. L. (2015). Chinese mindset: theories of intelligence, goal orientation and academic achievement in Hong Kong students. Educational Psychology, 35(6), 714-725. doi:10.1080/01443410.2014.893559

Chen, Z. C. (2014). SPSS 与统计分析 [SPSS and statistic analysis]. Beijing: Educational Science Publishing House.

Dupeyrat, C., \& Mariné, C. (2005). Implicit theories of intelligence, goal orientation, cognitive engagement, and achievement: A test of Dweck's model with returning to school adults. Contemporary Educational Psychology, 30, 43-59. doi:10.1016/j.cedpsych.2004.01.007

Dweck, C. S. (2000). Self-theories: Their role in motivation, personality, and development. New York: Psychology Press.

Dweck, C. S. (2006). Mindset: The new psychology of success. New York: Random House.

Dweck, C. S. (2017). Mindset: Changing the way you think to fulfil your potential. London: Hachette UK.

Dweck, C. S., \& Leggett, E. L. (1988). A social-cognitive approach to motivation and personality. Psychological Review, 95(2), 256-273. doi:10.1037/0033-295X.95.2.256

Dweck, C. S., Walton, G. M., \& Cohen, G. L. (2014). Academic tenacity: Mindsets and skills that promote long-term learning. Seattle, WA: Bill \& Melinda Gates Foundation. 
Finnish National Agency for Education. (2016). National core curriculum for basic education 2014. Helsinki: Finnish National Board of Education.

Gunderson, E. A., Gripshover, S. J., Romero, C., Dweck, C. S., Goldin-Meadow, S., \& Levine, S. C. (2013). Parent praise to 1-to 3-year-olds predicts children's motivational frameworks 5 years later. Child Development, 84(5), 1526-1541. doi:10.1111/cdev.12064

Guo, S. (2005). Exploring current issues in teacher education in China. Alberta Journal of Educational Research, 51(1), 69-84.

Hauke, J., \& Kossowski, T. (2011). Comparison of values of pearson's and spearman's correlation coefficients on the same sets of data. Quaestiones Geographicae, 30(2), 87-93. doi:10.2478/v10117-011-0021-1

Jonsson, A. C., \& Beach, D. (2012). Predicting the use of praise among pre-service teachers: The influence of implicit theories of intelligence, social comparison and stereotype acceptance. Education Inquiry, 3(2), 259-281.

doi:10.3402/edui.v3i2.22033

Kansanen, P. (2003). Teacher education in Finland: Current models and new developments. In B. Moon, L. Vlăsceanu, \& L. C. Barrows (Eds.), Institutional approaches to teacher education within higher education in Europe: Current models and new developments (pp. 85-108). Bucharest: European Centre for Higher Education.

Kuusisto, E., Laine, S., \& Tirri, K. (2017). How do school children and adolescents perceive the nature of talent development? A case study from Finland. Education Research International 2017, 1-8. doi:10.1155/2017/4162957

Leondari, A., \& Gialamas, V. (2002). Implicit theories, goal orientations, and perceived competence: Impact on students' achievement behavior. Psychology in the Schools, 39, 279-291. doi:10.1002/pits.10035

Leroy, N., Bressoux, P., Sarrazin, P., \& Trouilloud, D. (2007). Impact of teachers' implicit theories and perceived pressures on the establishment of an autonomy supportive climate. European Journal of Psychology of Education, 22(4), 529-545. doi:10.1007/bf03173470

Li, J. (2012). The Chinese model of teacher education: Retrospects and prospects over a century. Frontiers of Education in China, 7(3), 417-442. doi:10.3868/s110-001-0120022-2

Li, J. (2013). China's quest for world-class teachers: A rational model of national initiatives and institutional transformations. Asia-Pacific Journal of Teacher Education, 41(3), 316-330. doi:10.1080/1359866X.2013.809053

Makel, M. C., Snyder, K. E., Thomas, C., Malone, P. S., \& Putallaz, M. (2015). Gifted students' implicit beliefs about intelligence and giftedness. Gifted Child Quarterly, 59, 203-212. doi:10.1177/0016986215599057

Midgley, C., Maehr, M. L., Hruda, L. Z., Anderman, E., Anderman, L., Freeman, K. E., \& Urdan, T. (2000). Manual for the patterns of adaptive learning scales. Ann Arbor: University of Michigan.

Ministry of Education. (2002). 教育部关于“十五”期间教师教育改革与发展的意见 [The opinion on the reform and development of teacher education during the tenth five-year national plan period]. Retrieved from http://www.moe.gov.cn/srcsite/A10/s7058/200203/t20020301_162696.html

Ministry of Education. (2013). 教育部关于印发《中小学教师资格考试暂行办法》 《中小学 教师资格定期注册暂行办法》的通知 [Interim measures for the qualification examination of primary and secondary school teachers, interim measures for the regular registration of primary and secondary school teachers' qualifications]. Retrieved from http://www.moe.gov.cn/srcsite/A10/s7151/201308/t20130821_156643.html 
Niemi, H., \& Jakku-Sihvonen, R. (2011). Teacher education in Finland. In M. Valenčič Zuljan, \& J. Vogrinc (Eds.), European dimensions of teacher education: Similarities and differences (pp. 33-51). Ljubljana: University of Ljubljana.

Park, D., Gunderson, E. A., Tsukayama, E., Levine, S. C., \& Beilock, S. L. (2016). Young children's motivational frameworks and math achievement: Relation to teacherreported instructional practices, but not teacher theory of intelligence. Journal of Educational Psychology, 108(3), 300-313. doi:10.1037/edu0000064

Patterson, M. M., Kravchenko, N., Chen-Bouck, L., \& Kelley, J. A. (2016). General and domain-specific beliefs about intelligence, ability, and effort among preservice and practicing teachers. Teaching and Teacher Education, 59, 180-190. doi:10.1016/j.tate.2016.06.004

Rattan, A., Good, C., \& Dweck, C. S. (2012). “It's ok - Not everyone can be good at math": Instructors with an entity theory comfort (and demotivate) students. Journal of Experimental Social Psychology, 48(3), 731-737. doi:10.1016/j.jesp.2011.12.012

Rissanen, I., Kuusisto, E., Hanhimäki, E., \& Tirri, K. (2018). Teachers' implicit meaning systems and their implications for pedagogical thinking and practice: A case study from Finland. Scandinavian Journal of Educational Research, 62, 487-500. doi:10.1080/00313831.2016.1258667

Rissanen, I., Kuusisto, E., Tuominen, M., \& Tirri, K. (2019). In search of a growth mindset pedagogy: A case study of one teacher's classroom practices in a Finnish elementary school. Teaching and Teacher Education, 77, 204-213. doi:10.1016/j.tate.2018.10.002

Robins, R. W., \& Pals, J. L. (2002). Implicit self-theories in the academic domain: Implications for goal orientation, attributions, affect, and self-esteem change. Self and Identity, 1, 313-336. doi:10.1080/15298860290106805

Schmidt, J. A., Shumow, L., \& Kackar-Cam, H. (2015). Exploring teacher effects for mindset intervention outcomes in seventh-grade science classes. Middle Grades Research Journal, 10, 17-32.

State Council of People's Republic of China. (2010). 国家中长期教育改革和规划纲要 ( 2010-2020) [Outline of China's national plan for medium and long-term education reform and development (2010-2020)]. Retrieved from http://planipolis.iiep.unesco.org/sites/planipolis/files/ressources/china_natio nal_long_term_educational_reform_development_2010-2020.pdf

Tirri, K. (2014). The last 40 years in Finnish teacher education. Journal of Education for Teaching, 40(5), 600-609. doi:10.1080/02607476.2014.956545

Wen, H. J. (Ed.). (1989). Brief introduction to teacher training. Beijing: Beijing Teachers' University Press.

Yeager, D. S., Hanselman, P., Walton, G. M., Murray, J. S., Crosnoe, R., Muller, C., ... \& Paunesku, D. (2019). A national experiment reveals where a growth mindset improves achievement. Nature, 573(7774), 364-369. doi:10.1038/s41586-019-1466$\mathrm{y}$

Zhang, J., Kuusisto E., \& Tirri, K. (2017). How teachers' and students' mindsets in learning have been studied: Research findings on mindset and academic achievement. Psychology, 8(9), 1363-77. doi:10.4236/psych.2017.89089

Zhang, J., Kuusisto E., \& Tirri, K. (2019). How do students' mindsets in learning reflect their cultural values and predict academic achievement? International Journal of Learning, Teaching and Educational Research, 18(5), 111-126.

doi:10.26803/ijlter.18.5.8 